DOI: https://doi.org/10.32836/2521-666X/2018-2-60-12

УДК 659.1.013

\title{
Скригун Н.П.
}

кандидат економічних наук, доцент,

Національний університет харчових технологій

\section{Капінус Л.В.}

кандидат економічних наук, доцент, Національний університет харчових технологій

\section{Даценко І.М.}

студентка,

Національний університет харчових технологій

\section{АСОЦІАТИВНА ДИФЕРЕНЦІАЦІЯ БРЕНДІВ ТА МЕТОДИ ЇЇ ДОСЛІДЖЕННЯ}

Розглянуто теоретичні аспекти асоиіативної диферениіаиії брендів. Наведено основні переваги від застосування асоиіацій у диференціюванні брендів задля забезпечення ефективної роботи підприємства. Визначено умови, що їх необхідно дотримуватися під час дослідження асоиіаиій з брендами задля створення карти асоиіацій. Узагальнено основні проблеми, щяо виникають на шляху виявлення та аналізу асоціацій. Надано практичні рекомендації щодо проведення досліджень для виявлення асоціацій з брендами.

Ключові слова: асочіаџіï брендів, диферениіачія брендів, асоціативна сітка бренду, позииіонування, сенсорні асоиіаміï.

Рассмотрены теоретические аспекты ассоциативной дифференциащии брендов. Показаны основные преимущества от применения ассоциаций в дифференщировании брендов для обеспечения эффективной работы предприятия. Определены условия, которые необходимо соблюдать при исследовании ассоииаций с брендами для создания карты ассоциаций. Обобщены основные проблемы, возникающие на пути выявления и анализа ассоџиаџий. Разработаны практические рекомендаџии по проведению исследований для выявления ассочиаџий с брендами.

Ключевые слова: ассощиащии брендов, дифференщииачия брендов, ассоичитивная сеть бренда, позициионирование, сенсорные ассоциации. 


\section{Skrygun N.P., Kapinus L.V., Datsenko I.M. ASSOCIATIVE DIFFERENTIATION OF BRANDS AND METHODS OF ITS RESEARCH}

Theoretical basis of associative differentiation of brand and main methods of its research are determined. The enterprise in the modern competitive conditions tries to improve brand's attribute that form customers' associations of products and can be both positive and negative. It is necessary to make the monitoring and permanent research of association for creating and improving effective brand that is different from competitive one. Associative differentiation is more effective than differentiation only with the help of physical characteristics of the product, thus, it is very difficult to prove the customers' advantages only with the help of physical characteristics that can be similar with competitive brand is considered in the article. The main associative advantages in the creation of brand are given and determined. Their presence helps customers to remember the brand according its unique characteristics; help brand to differ from competitive one; motive in making decision about brand purchasing; form positive attitude or feeling to the brand; form the base to brand expanding. There are four means of brand's association presence: verbal, visual, sensitive and emotional. Associations are divided into constitutional and creative. Constitutional associations are very difficult to control, that is why companies create association that help them in achieving their objectives. Creative association have to involve three indexed that outline customer's wishes: 1. Brand bonus payment (competitive advantage that is connected with continuous effectiveness and profitability); 2. Recommend the brand to other customers; 3. Brand expanding (competitive advantages that are connected with potential increase). The main recommendations that necessary to keep during the research of brand associations in the enterprise are determined in the article. They are: using of one of the verbal technique; appliance of one of object and project technique; searching for showing secondary associations; demonstration of appropriate situations; consistent demonstration of sensitive associations; using of real indexes; giving opportunities to responders for answers' thinking; confidence providing; methods of self-project improving; using of polling survey for determining the relationship between associations; force; iniquity of associations; dividing polling survey into two and more groups of responders.

Key words: brand associations, brand differentiation, associative brand network, positioning, sensory associations.

Постановка проблеми. У сучасних умовах функціонування підприємств будь-якої галузі важливим є забезпечення стійких відносин споживачів з брендами підприємства. Оскільки сучасним підприємствам доводиться працювати в умовах перенасиченості ринку брендами, кожен з яких викликає у споживача певні емоції, враження, образи, уявлення, що узагальнено можна назвати асоціаціями бренду, необхідно створювати всі умови задля диференціювання одного бренду від іншого. Часом власникам брендів досить складно диференціювати бренд, адже за фізичними характеристиками він $\epsilon$ схожим на бренд конкурента, і тоді необхідно звертатися до почуттів, асоціацій споживача. Асоціативна диференціація допоможе споживачам швидко знайти відмінність між подібними брендами та надати раціональне пояснення здійсненим покупкам, що гарантуватиме задоволення від здійсненого вибору. Не всі асоціації брендів, які виникають у споживачів, є природними, деякі з них все ж $є$ штучно створеними підприємством для управління ними. Оскільки маркетингова поведінка підприємства залежить від маркетингової поведінки споживачів, виникає необхідність дослідження ролі асоціацій бренду в його диференціації та послідуючих діях підприємства.

Аналіз останніх досліджень та публікацій. Нині все більше вчених приділяють увагу дослідженню асоціативних диференціацій бренду та їх ролі в маркетинговій поведінці підприємства. Дослідження асоціацій бренду, класифікації та важливості ї моніторингу і вдосконалення висвітлювали в своїх працях вчені Д. Аакер, Дж. Паул, В. Перция, В. Редько, С. А. Старов, Ф. Котлер, С. Р. Кумар, Р. Дж. Фішер та інші. Проте багато питань, що пов'язанні $з$ роллю асоціативної диференціації в маркетинговій поведінці підприємства та проблематикою вимірювання бренд-асоціацій підприємства залишаються недостатньо дослідженими. Зокрема, потребують подальшого вивчення ролі асоціацій у побудові бренду підприємства та вигод, які отримає компанія, способів 
сприйняття асоціацій, проблем, що виникають у побудові та управлінні бренд-асоціацій та подальшої поведінки підприємства.

Мета статті - теоретичне обгрунтування та розроблення науково-практичних рекомендацій щодо дослідження асоціативної диференціації брендів задля посилення позицій брендів у свідомості споживача.

Виклад основного матеріалу. У сучасних умовах ринку постає необхідність у диференціюванні власного бренда від брендів-конкурентів задля завоювання споживачів. Способи диференціації брендів можуть бути пов'язані безпосередньо з фізичними характеристиками товару або з почуттями, враженнями, емоціями, уявленнями про бренд, під час контакту 3 його атрибутами, тобто 3 асоціаціями, які виникають у споживача. Асоціативна диференціація є більш дієвим методом, адже складно довести споживачу переваги за допомогою лише фізичних характеристик, які можуть бути подібними з брендом-конкурентом.

В. Перція виділяє поняття «асоціативна мережа (сітка) бренда», що визначається як зв'язки, що існують між брендом та іншою інформацією, яка зберігається в пам'яті людини [3, с. 46].

Асоціації брендів допомагають створювати цінність бренда навколо нього та $\epsilon$ основою сприйняття бренда [4]. Асоціації мають створювати позитивне ставлення i почуття. Бренди ж допомагають розвивати ці асоціації завдяки маркетинговій діяльності підприємства.

Також асоціації брендів можуть розвиватися поза контролем бізнесу. Невдалий журналістський огляд або негативні відгуки, які поширюються в соціальних мережах, можуть завдати шкоду бренду та створити нові асоціації у свідомості споживачів.

Асоціації брендів $\epsilon$ важливою частиною побудови бренда. Зокрема, вони можуть: допомогти покупцям запам'ятати бренд за його унікальні властивості; допомогти вирізнятися від конкурентів; мотивувати у прийнятті рішення про покупку бренду; створювати позитивне ставлення або почуття до бренда; створюють основу для розширень бренда [6].
Зазвичай асоціації брендів сприймаються як словесні описи бренду. Проте психологічні теорії визначають словесний опис бренду як один з методів подання інформації про асоціації, що виникають у споживачів. 3'ясовано, що більшість асоціацій не $\epsilon$ словесними, а мають візуальне відображення без відповідних словесних описів. I це виправдано, адже дві третини всієї інформації, що сприймається мозком людини, $є$ візуальною. Споживач постійно здійснює візуальні спостереження навколишнього середовища. Лише невелика частина цих вражень - тих, що навмисно вивчається і піддається когнітивній розробці, - матиме словесний вигляд під час запам'ятовування [9].

Окрім словесних і візуальних уявлень, асоціації брендів також зберігаються у вигляді сенсорних вражень, тобто когнітивних зображеннях фізіологічного сприйняття смаку, запаху, звуку тощо.

Асоціації брендів також можуть бути представлені в пам'яті як емоційні враження. Емоції від бренду - це нейронні, невербальні оцінки під час контакту з брендом. Дослідження показали, що є чотири способи подання асоціацій брендів: словесні, візуальні, сенсорні та емоційні. Важливою характеристикою асоціацій брендів є те, що більшість із них є підсвідомими. Це означає, що лише незначна частка вражень, що сприймається мозком людини, підлягає обгрунтуванню [9].

Інша важлива характеристика асоціацій брендів полягає в тому, що асоціації (незалежно від методу подання), як правило, повинні бути виражені у вигляді метафор, тобто розкриття сутності одного предмета чи явища через особливості іншого. Використання метафори $є$ ефективним способом комунікації, тому що метафори використовують знання i, таким чином, вимагають меншого когнітивного потенціалу.

Останній аспект асоціацій полягає в тому, що в межах великої асоціативної мережі вони, як правило, об'єднуються в кластери. Деякі асоціації більш тісно пов'язані один 3 одним, оскільки вони беруть участь в одних і тих самих пізнавальних процесах, зокрема, оцінюючи бренд у певній ситуації [9]. 
Деякі асоціації будуть частиною багатьох кластерів, але деякі будуть знайдені лише у кластерах, що відповідають конкретним ситуаціям, пов'язаних із брендом. Це означає, що важливі асоціації, які належать до контексту досвіду бренда (наприклад, місця споживання) зберігаються в окремих епізодичних спогадах. Одним з важливих наслідків цих аспектів пам'яті є те, що деякі асоціації можуть виникати, якщо навіть відповідні ситуації не будуть виявлені. Таким чином, під час дослідженні асоціацій брендів необхідно виявляти ситуації, в яких споживачі мали досвід роботи з брендом.

Дослідження асоціацій брендів показують, що вони позитивно впливають на споживчий вибір, переваги та намір здійснення покупки, готовність платити премію за бренд, прийняти бренд та порекомендувати його іншим. Формування іміджу бренду має зосереджуватися на об'єднанні всіх асоціацій брендів в єдиний вимір [8, с. 57].

Компанія займається створенням асоціацій задля досягнення власних цілей, адже органічні асоціації неконтрольовані і можуть відрізнятися від тих, які прогнозувала компанія. Для успішного просування брендів необхідно створювати асоціації, які підкріплюють базові вигоди для клієнта (безпека, професіоналізм, контроль або влада). Асоціації допомагають клієнтам оцінити значущі враження, які їм надасть бренд. Асоціації також $€$ способом встановлення тісніших відносин 3 клієнтом.

Створювані асоціації мають підкріплювати три змінні, що відображають бажання споживача: 1. сплатити премію за бренд (кон- курентна перевага, що пов'язана 3 поточною ефективністю та рентабельністю); 2. рекомендувати бренд іншим; 3. прийняти розширення бренду (конкурентні переваги, що пов'язані з потенціалом зростання) [6].

Д. Аакер виділяє низку вигод від використання асоціацій під час побудови бренда (рис. 1).

Щодо вигоди «сприяння в засвоєнні інформації», то асоціації створюють стисле інформаційне поле в пам'яті, яке дають змогу цілеспрямовано зосереджувати численні відомості навколо імені бренду. Асоціації впливають на інтерпретацію фактів і згадування інформації, особливо під час прийняття рішення про покупку. Деякі компанії активно використовують метод асоціацій в спробі закріпити за кожним $з$ власних брендів певний образ в свідомості споживача.

Цінність асоціацій у диференціюванні або позиціонуванні брендів полягає в тому, що асоціації сприяють чіткому розподілу брендів у свідомості споживачів. У низці товарних категорій, таких як виробництво молочної продукції, парфумерія або одяг більшість брендів малопомітні споживачам за функціональними ознаками.

Асоціації з емоційними і символьними характеристиками, індивідуальністю бренда здатні зіграти вирішальну роль у відмінності одного марочного продукту від іншого. Багато асоціацій, пов'язаних 3 брендом, включають в себе унікальні позитивні характеристики товару або цінності від його придбання, що зумовлює мотивацію до здійснення покупки i використання саме цього бренду. Стійке позитивне ставлення до бренду, засноване на

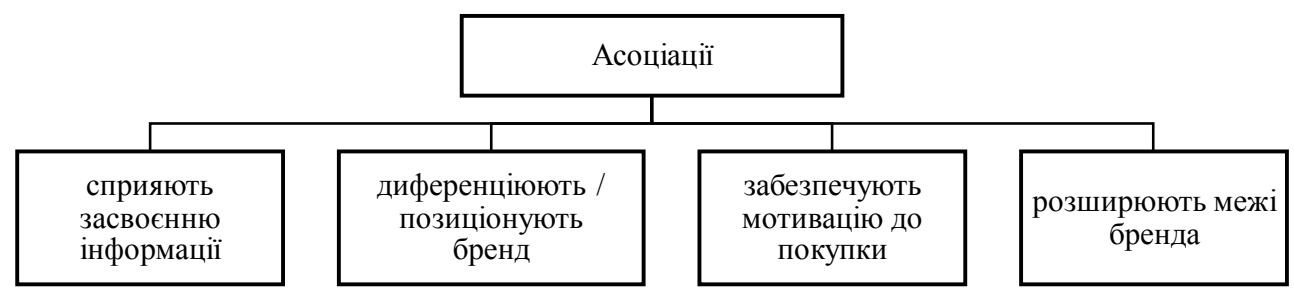

Рис. 1. Цінності, що створюються за допомогою асоціацій із брендом Джерело: [5, с. 146] 
сильних позитивних асоціаціях з ним, формує сильну марочну прихильність $[1$, с. 86].

Асоціації, що становлять основу стрижневої ідентичності бренду і стійко укорінені в свідомості споживачів, можуть сприяти успішному виходу марочного продукту в інші товарні категорії. Під час дослідження асоціацій брендів можуть виникати певні проблеми, що пов'язані з їх вимірюванням: проблема доступу; проблема вербалізації; проблема цензури [9].

Щодо доступу більшість асоціацій брендів $\epsilon$ неусвідомлюваними. Тому часто виявляються лише легко здобуті асоціації, і тоді менеджери підприємств отримують неоднозначну картину своїх брендів. Найважливішою проблемою під час виявлення асоціацій брендів є отримання доступу до менш свідомих асоціацій. Проблема вербалізації тісно пов'язана $з$ проблемою доступу. Несвідомі асоціації переважно $є$ невербальними. Вони $\epsilon$ сильними враженнями, представленими у візуальних, чуттєвих або емоційних режимах, і не піддаються активному когнітивному виміру.

Погоджуємося 3 думкою, що для вирішення цих проблем, які не дають можливості отримати повну карту асоціацій, необхідно під час дослідження асоціацій брендів дотримуватися основних умов: довгі особисті бесіди, вибір оптимальних методів дослідження, перевірка відповідей. Необхідність проведення довгих особистих співбесід замість коротких інтерв'ю у фокус-групах пояснюється тим, що фокусні групи варто застосовувати в основному у випадках, коли метою дослідження $€$ вивчення соціальних реакцій на стимули бренда або отримання творчої відповіді на нові концепції чи продукти. Традиційні фокус-групи $\epsilon$ не найкращою альтернативою для поглибленого виявлення асоціацій брендів. Гібридні фокус-групи та системи підтримки груп (GSS) пропонують значні покращення порівняно 3 традиційними фокус-групами. Зокрема, використання GSS, що передбачає використання учасниками складного програмного забезпечення на окремих робочих місцях, повинно полегшити проблеми цензури, пов'язані з традиційними опитуваннями фокус-груп. Проте довгі особисті співбесіди $€$ пріоритетнішими, оскільки вони мають великий потенціал заглибитися в спогади респондентів за допомогою довгої, особистої та індивідуально адаптованої бесіди.

Обрання портфеля методів, що доповнюють три проблеми доступу, вербалізації та цензури, - важлива умова створення карти асоціацій. Одного методу, як правило, недостатньо для подолання всіх перешкод, що виникають під час дослідження асоціацій $з$ брендом. Замість цього слід вибрати ретельно відібраний портфель методів.

3 метою уточнення результатів дослідження необхідна перевірка відповідей. Коли споживача безпосередньо запитують про асоціації брендів, то дослідник може бути впевненими, що отримує особисту думку споживача про бренд. Однак, як уже зазначалося раніше, ймовірно, він отримує лише «верхівку айсберга». Коли під час дослідження бренду застосувати непрямі методи дослідження асоціацій брендів, такі як візуальні та проектні методи, то збільшується ймовірність виявлення прихованих асоціацій, але водноча збільшується ризик виникнення спотворених асоціацій [9].

На основі виявлених проблем було розроблено практичні рекомендації, яких необхідно дотримуватися під час дослідження асоціативних зв'язків (табл. 1).

Візуальні прийоми під час аналізу асоціацій брендів дозволять респондентам швидше пригадати емоції, що пов'язані у них $з$ досліджуваним брендом. Одним із таких прийомів $\epsilon$ метод «налаштування», в якому респондентам пропонується вибирати зображення 3 журналів або газет, які відображають те, що вони думають або відчувають про бренд. Респонденти описують зображення, а асоціації виводяться 3 контент-аналізу опису. Такі методи можуть бути корисними для виявлення несвідомих сенсорних та емоційних асоціацій про бренди.

Застосування проектно-об'єктивних методів має на меті змусити респондентів 
Таблиця 1

Практичні рекомендації під час дослідження асоціацій брендів

\begin{tabular}{|c|c|}
\hline Рекомендація & Мета \\
\hline $\begin{array}{l}\text { 1. Застосування хоча б однієї } \\
\text { візуальної техніки }\end{array}$ & $\begin{array}{l}\text { Застосування прийомів для швидшого згадування респондентами емо- } \\
\text { цій, що пов'язані } 3 \text { досліджуваним брендом. Використання методик, } \\
\text { що засновані на використанні метафор та контент-аналізі опису зобра- } \\
\text { ження. }\end{array}$ \\
\hline $\begin{array}{l}\text { 2. Застосування хоча б однієї } \\
\text { об'єктно-проективної техніки }\end{array}$ & $\begin{array}{l}\text { Змусити споживача описати досліджуваний бренд, посилаючись на } \\
\text { об'єкти або живих істот. Застосовується за неможливості дослідження } \\
\text { бренду за допомогою візуальних технік. }\end{array}$ \\
\hline $\begin{array}{l}\text { 3. Зондування для виявлення } \\
\text { вторинних асоціацій }\end{array}$ & $\begin{array}{l}\text { Застосування первинних асоціацій як стимулу для дослідження вто- } \\
\text { ринних асоціацій бренду. }\end{array}$ \\
\hline $\begin{array}{l}\text { 4. Виявлення відповідних си- } \\
\text { туацій }\end{array}$ & $\begin{array}{l}\text { Виявлення ситуацій, з якими респонденти пов'язують бренд або кон- } \\
\text { тактують із ним. }\end{array}$ \\
\hline $\begin{array}{l}\text { 5. Послідовне виявлення сен- } \\
\text { сорних асоціацій }\end{array}$ & Виявлення сенсорних асоціацій покроково, а не одночасно. \\
\hline $\begin{array}{l}\text { 6. Використання натураль- } \\
\text { них подразників }\end{array}$ & Використання фізичних стимулів для виявлення додаткових асоціацій. \\
\hline $\begin{array}{l}\text { 7. Надання можливості рес- } \\
\text { пондентам для обдумування } \\
\text { відповідей }\end{array}$ & Заохочення респондентів ретельно обдумувати відповіді \\
\hline $\begin{array}{l}\text { 8. Забезпечення конфіденцій- } \\
\text { ності }\end{array}$ & Інформування респондентів про конфіденційність їх відповідей. \\
\hline $\begin{array}{l}\text { 9. Застосування особистіс- } \\
\text { но-проективних методів }\end{array}$ & $\begin{array}{l}\text { Надання можливості респондентам відповідати від імені певної особи } \\
\text { або групи, до якої належать респонденти }\end{array}$ \\
\hline $\begin{array}{l}\text { 10. Використання опитувань } \\
\text { задля визначення взаємовід- } \\
\text { носин між асоціаціями, сили, } \\
\text { сприятливості та унікальності } \\
\text { асоціацій }\end{array}$ & $\begin{array}{l}\text { Використання кількісних вимірювань для виявлення взаємозв'язків } \\
\text { між асоціаціями брендів. }\end{array}$ \\
\hline $\begin{array}{l}\text { 11. Розбиття вибірки на дві i } \\
\text { більше групи респондентів }\end{array}$ & \begin{tabular}{|l} 
Розподіл опитуваних на групи задля можливості використання для \\
кожної групи оптимального для неї методу дослідження.
\end{tabular} \\
\hline
\end{tabular}

Джерело: складено авторами на основі [9]

проектувати значення на якийсь об'єкт (об'єктно-проективні методи) або особистість (особистісно-проективні методи). Зондування для вторинних асоціацій передбачає допомогу респонденту виявити не лише первинні асоціації, які виникають у нього відразу під час згадування про бренд, а й вторинні асоціації. Перші асоціації, які виникають у споживачів, $\epsilon$ найбільш усвідомлюваними та згадуваними і не потребують значного поглиблення в спогади. Простий спосіб глибше вивчити асоціації та побудувати асоціативну сітку полягає в тому, щоб використовувати ці первинні асоціації як слова, що стимулюють до згадування вторинних асоціацій (наприклад, «що ви пов'язуєте з якістю?»). Деякі важливі вторинні асоціації можуть бути основою для виявлення наступного рівня асоціацій. Ця техніка характеризує те, наскільки багатогранним є характер первинних асоціацій.

Рекомендація щодо розгляду сенсорних асоціацій послідовно передбачає фіксування важливих почуттів і вражень поступово, а не комплексно (наприклад, «які звуки Ви асоціюєте $з$ брендом?»).

Використання справжніх подразників передбачає використання фізичних стимулів для того, щоб викликати додаткові асоціації. Наприклад, перед тим як опитувати користувачів бренду кави про асоціації, можна запропонувати їм скуштувати іiі. Перевага використання реальних стимулів полягає в тому, що первинні емоційні та чуттєві асоціації, що активізуються безпосереднім досвідом. 
Тому менш усвідомлювані вторинні асоціації легше активізуються. Використання реального досвіду продукту як стимулів особливо рекомендується застосовувати під час дослідження продуктів та брендів, що зосереджують увагу на сенсорних перевагах. Проте інші види реальних подразників також ефективні, наприклад, це можуть бути елементи бренда. Елементи бренда - це ті фізичні елементи, які ідентифікують бренд, такі як фірмова назва, логотип, символи бренда, слоган тощо.

Незалежно від методу дослідження важливо, аби у респондентів було досить часу для обдумування відповіді на питання. Часто інтерв'ю проходять швидко та без довгих пауз, тому респонденти можуть відчувати себе незручно, не знайшовши відповідних слів для опису асоціацій бренду. і можуть давати відповідь, що не відповідає дійсності, що спотворює результати дослідження [9]. Забезпечення конфіденційності допоможе респондентам відчувати себе вільно під час опитування та бути впевненими, що їхні відповіді не будуть повідомлені третім особам або використані для рекламних цілей.

Також рекомендується використовувати особистісно-проективні методи (ОПМ), що необхідні для найбільш глибоких асоціацій, які особа не бажає озвучувати від свого імені. Під час їх використання респондентам пропонується розповідати про асоціації від імені певної особи, що належить до тієї ж групи, що і респондент [7].

Вважаємо, що у процесі дослідження варто розбити вибірку на дві або більше групи респондентів. Часто під час досліджень асоціацій брендів застосовується не один, а одразу декілька методів. Респондентів це втомлює, і відповіді на запитання $є$ нечіткими і неякісними. Тому не рекомендується застосовувати одразу багато методів на одних і тих самих опитуваних, потібно розділити їх на групи i для кожної групи застосувати окремий метод.

Висновки 3 цього дослідження та перспективи подальших розвідок у цьому напрямі. Прагнучи виділити, диференціювати власний бренд, ефективно функціонувати на ринку та бути конкурентоспроможними, підприємства повинні постійно здійснювати моніторинг та контроль над асоціаціями бренда 3 метою виявлення недоліків та своєчасного їх усунення 3 метою сформувати і не втратити лояльних клієнтів, пов'язаних із брендом тісними взаємозв'язками. Асоціації $є$ необхідним інструментом бренда, що формує уявлення про цінність та обіцянки бренда та залишається у пам'яті споживача. Дії всіх учасників ринку взаємопов'язані, тому, створивши певні асоціації бренда, підприємство чекає відповідної реакції від споживача, так само і споживач, диференціювавши цей бренд від інших, очікує відповідної дії підприємства, яка би підкріплювала створювані асоціації. Важливим напрямом діяльності підприємства та предметом подальших наукових розвідок вважаємо пошук шляхів формування тісних зв'язків зі споживачами, що гарантує лояльність до бренду, досягнення підприємством цілей та ефективне його функціонування.

\section{Список використаних джерел:}

1. Аакер Д. Создание сильных брендов/ М.: Издательский Дом Гребенникова. 2003. 439 с.

2. Котлер Ф. Маркетинг менеджмент. 15-е изд./ СПб.: Питер. 2018. 848 с.

3. Перция В. Анатомия бренда / СПб: Вершина. 2007. 222 с.

4. Редько В. Раскрываем механизмы восприятия бренда. URL: https://koloro.ru/blog/ brending-i-marketing/raskryivaem-mehanizmyi-vospriyatiya-brenda.html

5. Старов С. А. Управление брендами / СПб: Изд-во «Высшая школа менеджмента». 2008. 500 с.

6. Exploring the identity of a brand: How to discover and measure brand associations. URL: https://www.brandwatch.com/blog/discover-measure-brand-associations

7. Fisher R. J. Social desirability bias and the validity of indirect questioning. URL: http://www.ejcr.org

8. Kumar S. R. Marketing and Branding: The Indian Scenario/ Pearson Education India. 2007. 482 c.

9. Pawle J. Understanding core brand equity: guidelines for in-depth elicitation of brand associations. URL: https://www.warc.com/fulltext/JMRS/142 56.htm 